\title{
Betonarme Manto Uygulamasının Prefabrike Yapıların Deprem Performansına Etkisi
}

\author{
Cihan SOYDAN ${ }^{\circledR}$, Hasan ÖZKAYNAK ${ }^{*}$ ¿ \\ ${ }^{1}$ Namık Kemal Üniversitesi, Çorlu Mühendislik Fakültesi, İnşaat Mühendisliği Bölümü, 59850, Tekirdağ, Türkiye \\ ${ }^{2}$ Beykent Üniversitesi, Mühendislik ve Mimarlık Fakültesi, İnşaat Mühendisliği Bölümü, 34398, İstanbul, Türkiye
}

(Alınış / Received: 15.09.2018, Kabul / Accepted: 10.05.2019, Online Yayınlanma / Published Online: 30.08.2019)

\begin{abstract}
Anahtar Kelimeler Betonarme mantolama, Prefabrike yapılar, Dinamik analiz, Taban kesme kuvveti, Şekil değiştirme düzeyi
\end{abstract}

Özet: Ülkemizdeki sanayi yapıların çoğunluğunu, kolon-kiriș birleșim bölgelerinde moment aktarımı olmayan tek katlı prefabrike sistemleri oluşturmaktadır. Yaşanmış depremler sonrasında yapılan gözlemler; prefabrike yapıların deprem etkisi altında yüksek yatay yerdeğiştirmeleri nedeniyle kolon-kiriş birleşim bölgelerinde ve yapı genelinde önemli hasarların oluștuğunu göstermiștir. Bu tip yapı sistemlerinin depreme karșı güçlendirilmesi, sadece yüksek maliyetli cihazlar için değil öncelikli olarak insan yaşamı açısından hayati önem taşımaktadır. Bu çalışmada betonarme (BA) mantolama yönteminin prefabrike yapıların deprem performansındaki rolü sayısal olarak incelenmiştir. Çalışmanın ilk bölümünde, literatürde deneysel sonuçları yer alan BA mantolu ve mantosuz kolonların nümerik modelleri oluşturulmuştur. Tersinir tekrarlı yerdeğiștirme protokolü etkisi altında yapılan deneylerden elde edilen yükyerdeğiştirme ilişkileri, oluşturulan nümerik model sonuçları ile karşıllaştırılmıştır. Nümerik modeller, belirli yerdeğiştirme eşikleri arasında deneysel sonuçları iyi bir șekilde tahmin edilebilmektedir. Deneysel olarak kalibre edilmiș olan nümerik model, üç boyutlu sanayi tipi mevcut bir yapı sisteminin lineer olmayan dinamik analizlerinde kullanılmıștır. Sayısal sonuçlar, mantolama sayesinde prefabrike yapının ortalama en büyük ve en küçük göreli ötelemelerin \%54 ile \%72 arasında değișen oranlarda azaldığını göstermiştir. Mevcut yapının seçilen kolonları, birim şekildeğiştirme açısından değerlendirildiğinde; güvenlik sınırı (GV) civarında olan kesit performansının BA mantolama ile minimum hasar sınırının (MN) altına çekildiği görülmüştür.

\section{The Effects of Reinforced Concrete Jacketing on the Earthquake Performance of Precast Structures}

\section{Keywords}

Reinforced Concrete Jacketing,

Precast Structures, Dynamic Analysis,

Base Shear Force,

Strain level

\begin{abstract}
The majority of industrial buildings located in our country consist of single-story precast systems with pinned beam-to-column connections. Observations made after earthquakes showed that due to high lateral displacement demands occurred under the effects of earthquake loads; significant damage was accumulated throughout the beam-to-column connections and whole structure. Strengthening such building systems against earthquake loads is not only crucial for high-cost devices and machinery but also very important in terms of human life as a priority. In this study, the effects of reinforced concrete (RC) jacketing technique on the global earthquake performance of precast structures was examined numerically. In the first part of the study, experimental results of bare and RC jacketed columns, which exist in the recent literature, were used as a benchmark for the development of numerical models. The force-displacement relations obtained from quasi-static experiments were compared with the numerical results. The numerical models are successful to estimate the experimental results within the range of distinct displacement levels. Validated numerical models were used for nonlinear dynamic analysis of an existing 3D precast system. Numerical results showed that the application of $\mathrm{RC}$ jacketing technique is effective to decrease the average maximum and minimum drift values by the ratios of 54-72\%. Determinations of strain levels for the selected columns of the system showed that; the RC jacketing retrofitting technique is effective to increase the sectional performance by shifting the strain demands from safety limit $(G V)$ to minimum damage limit $(M N)$.
\end{abstract}




\section{Giriş}

Ülkemizde yeralan tek katlı geniş açıklıklı prefabrike betonarme (BA) yapıların önemli bir bölümü endüstriyel amaçlı olarak kullanılmaktadır. Mevcut prefabrike yapıların çoğunluğunun kolon-kiriş birleşim bölgeleri, moment aktarımı olmayacak şekilde tasarlanmakta olup temel bölgelerinde soket tipi birleşim detayı öngörülmektedir. Bu tip yapısal özellikleri nedeniyle özellikle 1998 deprem yönetmeliği öncesi inşa edilen prefabrike yapıların çoğunluğunun deprem dayanımının yetersiz olduğu görülmektedir, [1].

Prefabrike yapılarda gözlenen en önemli hasar tipleri; kolonların taban kesitlerinde eğilme tipi plastik mafsalların oluşması ve çatı seviyesinde oluşan büyük göreli hareketten dolayı çatı düzleminde bulunan yapı elemanlarının taşıyıcı sistemden deprem sırasında ayrılmasıdır, [2], [3]. Söz konusu hasar tipleri Şekil 1 'de görülmektedir.

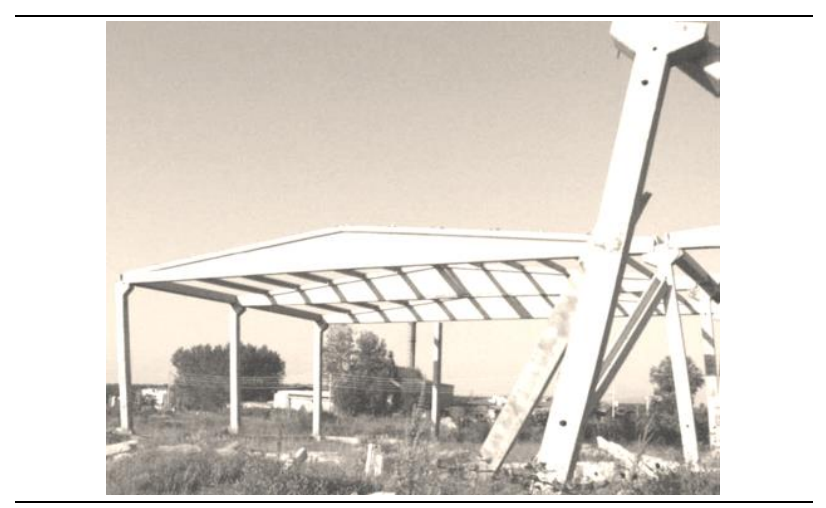

a) Tașıyıcı sistemin genel hasarı

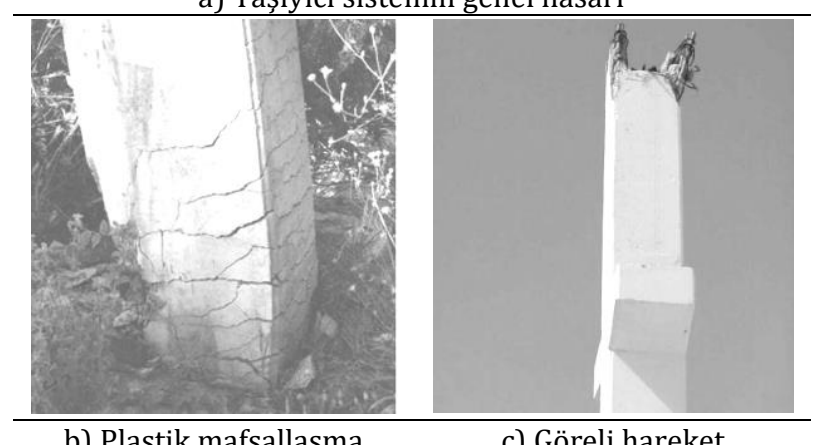

b) Plastik mafsallașma

Şekil 1: Prefabrike yapı hasar tipleri $[2,3]$

Prefabrike yapıların çatı düzlem içi rijitliklerinin sağlanabilmesi ve çatıda yer alan yapı elemanlarının deprem sırasında göreli hareketlerinin azaltılması için Wang vd. [3], bir kablo sistemi önerisinde bulunmuştur. Bu kapsamda gerçekleştirilen analitik çalışmalarda; kablo sisteminin düzlem içi çatı rijitliğinin artırılmasında ve çatı göreli hareketinin azaltılmasında etkili olduğu görülmüştür. Düzlem için çatı rijitliğinin sağlanması; yapıya etkiyen atalet kuvvetlerinin tüm yapı boyunca düzgün dağılımı sağlanması ve yapı yatay rijitliğine katkıda bulunan kolon sayısının artmasından dolayı yapının genel performansını iyileştirmektedir. Prefabrike yapıların kolonlarında betonarme mantolama uygulaması yapılarak, kolonların taban kesitinde oluşacak plastik şekildeğiştirmelerin ve yapıdaki tepe yerdeğiștirme istemlerinin azalması, dolayısıla yapılacak uygulamanın yapısal hasarın önlenmesi açısından etkili olacağı düşünülmektedir.

Prefabrike yapıların güçlendirilmesinde BA mantolama uygulanması; pratik olması ve ekonomisi gibi özelliklerinden dolayı öne çıkmaktadır. Betonarme mantolama yöntemi, kesit alanlarının artırılmasıyla mantolanan yapı elemanlarının taşıma kapasitelerini artırarak ve yapının tepe yerdeğiștirme seviyesini kısıtlayarak, muhtemel deprem hasarını azaltmayı hedeflemektedir. Uygulama açısından bazı zorluklar içermekle beraber, kendinden yerleșen özelliği olan betonun kullanılmasıyla döküm, kalıp içerisinde segregasyon oluşturmadan ince bir manto kalınlığı ile yapılabilmektedir. Betonarme mantolama yöntemi ile ilgili olarak literatürde çok sayıda deneysel çalışma olmasına rağmen, yöntemin prefabrike yapı performansına etkisinin tartışıldığı sınırlı sayıda nümerik çalışma bulunmaktadır. Marini ve Meda [4], 1/3 ölçekli BA perdelerin yüksek dayanımlı beton ve çelik malzeme kullanılarak mantolanması konusunda deneysel ve nümerik bir çalışma gerçekleştirmiştir. Deneysel sonuçlar, BA perdelere $15 \mathrm{~mm}$ kalınlığında yüksek performanslı beton ile uygulanan mantolamanın, perde elemanların yapısal dayanımlarını, deformasyon kapasitesini ve sünekliğini önemli ölçüde artırdığını göstermiştir. Minafo [5] ve Minafo vd. [6] betonarme mantolanmış kare kesitlerin eksenel yük ve eğilme etkisi altındaki eğilme dayanımının ve sünekliğinin hesaplanması için basitleștirilmiş bir yöntem önermiştir. Çalışma sonunda, gerilme bloğu esasına dayalı olarak önerilen yöntem ile belirlenen sonuçların deneysel sonuçlara oldukça yakın olduğu görülmüştür. Alejandra vd. [7], BA manto uygulanmasının köprü ayaklarının hasar görebilirliği üzerindeki etkisini, kırılganlık eğrileri kapsamında, 6 farklı güçlendirme durumu ve çok sayıda deprem senaryosu için nümerik olarak incelemiştir. Nümerik çalışmalar, her durum için BA mantolama etkisinin köprü ayağının kesme dayanımını artırdığını ve köprünün hasar görebilirliğini azalttığını göstermiştir. Dubey ve Kumar [8], kendinden yerleșen betonun ve çelik hasır tipi donatıların kullanıldığı manto uygulamasının BA silindirik kolonlar üzerindeki etkisini deneysel olarak incelemiştir. Deney sonuçları kendinden yerleşen betonun etkin olarak BA manto uygulamasinda kullanılabileceğini ve bu durumda kolon elemanların eksenel yük taşıma kapasitelerinin önemli ölçüde arttığını göstermiştir. Zayıf çekirdek betonu olan kesitin yüksek dayanımlı beton ile mantolanması durumunda manto uygulamasının sarglama etkisini arttırmasından dolayı kesitin şekildeğiștirme kapasitesinin arttığı görülmüştür. Kalogeropoulos ve Tsonos [9] yetersiz bindirme boyu ve etriye sıklaştırma aralığı olan kolon elemanlarda BA mantolama etkisinin belirlenmesi için bir seri deneysel çalışma tamamlamıştır. Betonarme mantolama uygulamasının yapıldığı numunelerin, 
sargı ve bindirme boyu yetersizliği olan numunelere göre, sismik performansının önemli ölçüde arttığı görülmüştür. Yüce vd. [10] tam ölçekli prefabrike BA kolon numuneleri, sabit eksenel normal kuvvet etkisi altında statik olarak test etmiştir. Test edilen ağır hasarlı prefabrike kolon numuneleri, BA manto uygulanmasıyla onarım ve güçlendirme sonrasında aynı normal kuvvet ve yerdeğiştirme çevrimleri uygulanarak tekrar denenmiştir. Güçlendirmede uygulama kolaylığı açısından kendiliğinden yerleşen beton kullanılarak dört taraftan $7.5 \mathrm{~cm}$ kalınlığında betonarme mantolama uygulaması yapılmıştır. Kolonlar toplam yüksekliklerinin 1/4'üne ve 1/2'sine kadar mantolanmıştır. Mantolanan kolonların taşıma kapasiteleri orijinal kolonların kapasitesinin 1.5 2 katı düzeyine çıkmıştır. Deneysel çalışma sonuçları, boyuna donatıların kopmasıyla ağır hasar gören kolonların betonarme mantolama ile tekrar geri kazanılabileceğini göstermiştir. Thermou vd. [11, 12] betonarme manto uygulaması yapılmış kolon elemanların monotonik ve tersinir tekrarlı yükler etkisindeki eğilme davranışını belirlemek için, ara yüzeyler arasında gerçekleşen sıyrılma davranışını da dikkate alan, analitik bir model geliştirmiştir. Modelin davranışı belirlemedeki başarısı deneysel sonuçlarla karşılaştırılmıştır. Yüzeyler arasında sıyrılma etkisinin modele dâhil edildiği durumda yükyerdeğiştirme ilişkisinde oyulma etkisinin öne çıtı̆̆ğ bir davranış görülmekte olup, daha düşük bir enerji tüketimi gerçekleșmiştir. Arslan vd. [1], tarafından yapılan çalışmada 1999 Kocaeli depreminde tamamen göçmüş olan bir prefabrike yapı, Türk Deprem Yönetmeliği-1998 [13], UBC-97 [14] ve Eurocode-898 [15] kapsamında analiz edilmiştir. Çalışma sonunda TDY-98'e göre hesaplanan kapasite değerlerinin, diğerlerinin verdiği değerlere göre daha düşük kaldığı sonucuna varılmıştır. Eduardo vd. [16, 17] farklı özellikte yüzey hazırlıkları yapılan küçük ölçekli kolonları monotonik ve tersinir tekrarlı yerdeğiştirme etkileri altında test etmiştir. Deney sonuçları, eğilme momenti/kesme kuvveti oranının 1.0 'den büyük olduğu ve eleman genişliğinin \%17.5 değerinden az olduğu durumda bütünsel davranışın elde edilmesi noktasında, ara yüzey pürüzlülüğünün artırılması, ek çelik vb. bağlayıcı eleman gibi herhangi bir yüzey hazırlığı yapılmasına ihtiyaç olmadığını göstermiştir. İlki vd. [18] tarafından tam ölçekli BA manto uygulaması yapılmıştır. Kare kesitli kolon deneylerinden elde edilen sonuçlar, manto ve çekirdek kesit arasında ek bir önlem almaya gerek kalmadan mantolu kesitte bütünsel davranışın sağlanabildiğini göstermiştir. Ersoy vd. [19] betonarme mantolama uygulamasının etkisini araştırmak amacıyla kolon numuneleri üzerinde iki farklı grupta deneyler yapmıştır. Birinci grupta eşdeğer boyut ve donatı oranlarına sahip 4 kolon tek yönlü olarak eksenel yük etkisinde test edilmiştir. Bu deneyler sonrasinda, hasar gören numuneler mantolanarak tekrar test edilmiştir. İkinci grup numunelerden 3 tanesi mantolanarak güçlendirilmiş, 2 tanesi monolitik olarak eşdeğer boyut ve donatı oranlarıyla üretilmiş ve eksenel yük ile eğilme etkisi altında test edilmiştir. Tek yönlü ve çevrimsel deneylerden elde edilen sonuçlar, güçlendirilmiş kolon numunelerinin diğerlerine göre her durumda daha iyi performans sergilediğini göstermiştir. Rodriguez ve Park [20] $35 \times 35 \mathrm{~cm}$ boyutlarında orijinal boyutlara sahip güçlendirilmemiş kolon numunelerini ve güçlendirilmiş kolon numunelerini statik olarak test etmiştir. Güçlendirilmemiş numunelerde enine donatılar düşük kalitede ve seyrek aralıklarla kullanılmıştır. Bu numunelerin kullanıldığı deney sonuçlarından dayanım kaybının görüldüğü sünek olmayan bir davranıș gözlenmiștir. Hasar gören numuneler BA manto uygulamasıyla güçlendirildikten sonra tekrar test edilmiş olup bu durumda sünek davranış, yüksek dayanım ve göreli olarak daha az dayanım kaybı elde edilmiștir. Vandoros ve Dritsos [21] betonarme manto uygulaması yapılmış numunelerde eksenel ön yüklemenin davranışa etkisini deneysel olarak araştırmıştır. Yapılan çalışmada eksenel ön yüklemenin numune başlangıç rijitliğini azalttığını ancak ilerleyen adımlarda rijitlik kaybının önlenerek enerji tüketiminin ön yükleme yapılmamış durumlara göre arttığını göstermiştir. Öztürk vd. [22] boyutları ve zemin koşulları farklı olan iki sanayi yapısının doğrusal olmayan dinamik davranışını incelemiştir. Analiz sonuçları, tasarımın mevcut yönetmeliklere göre yapılmış olmasına rağmen, yönetmelikte öngörülen güvenlik sınırlarının aşlabildiğini göstermiştir. Mevcut literatürde BA mantolama uygulamasının prefabrike yapıların doğrusal olmayan davranışındaki etkisi sınırlı düzeyde araştırılmıştır. Bu çalışmada, literatürde yer alan bir deneysel çalışma esas alınarak BA mantolama için nümerik model oluşturulmuştur. Deneysel çalışmanın sonuçları ile sayısal çalışma sonuçları karşılaştırıldığında, modelin belirli yerdeğiştirme hedefleri eşiklerinde başarılı olduğu sonucuna varılmıştır. Oluşturulan nümerik modellerde kullanılan varsayımların tamamı üç boyutlu gerçek bir prefabrike yapının güçlendirilmiş modelinin oluşturulmasında kullanılmıştır. Doğrusal olmayan dinamik analizler, BA mantolama uygulamasının yapının deprem performansını önemli seviyede arttırdığını göstermiştir. BA mantolama uygulaması ile prefabrike yapının en büyük ve en küçük göreli öteleme değerleri \%54 ile \%72 arasında değișen oranlarda azalmıştır. Şekildeğiştirme kapsamında yapılan değerlendirmeler, yalın durumdayken güvenlik sınırı (GV) performans seviyesi civarında olan kesitlerin mantolama uygulaması ile minimum hasar sınırının (MN) altına indiğini göstermektedir.

\section{Betonarme Mantolu Kolon Kesiti için Analitik Modelin Oluşturulması}

Betonarme mantolama uygulamasinın kolon yüksekliği boyunca devam etmesiyle eksenel yükler hem çekirdek kesite hem de BA manto kesitine aktarılabilmektedir. Söz konusu uygulama kolonun belirli bir yüksekliğine kadar yapılırsa bütünsel kesitte sargı etkisinin oluşturulması 
sağlanabilmektedir. Her iki durumda; kabuk betonun çekirdek kesitten sıyrılması, mantolamada ön yükleme etkisi, mantolamanın kesitin sargılanmasındaki etkisi ve boyuna donatılardaki burkulma olaylarından dolayı betonarme mantolu kesitin analitik olarak davranışının belirlenerek süneklik ve dayanım tahmininin yapılması oldukça karmaşık bir iştir [6]. Bu çalışmada, BA mantolu bir kesitin nümerik modelinin oluşturtulması ve oluşturulan modelin doğrulanması için literatürde yer alan Eduardo vd. [16, 17] tarafindan gerçekleştirilen kolon deneylerinin sonuçları kullanılmıştır. Deneysel çalışmada kullanılan deney düzeneği Şekil 2'de verilmiştir.

$\mathrm{Bu}$ çalışmalarda aynı deney düzeneği kullanılarak, yalın (M1) ve güçlendirilmiş (M5) numuneler tek yönlü ve çevrimsel yükler etkisi altında deneysel olarak incelenmiştir. Mantolu (M5) ve yalın (M1) kolonların tek yönlü ve çevrimsel yükler etkisi altındaki davranışının nümerik olarak belirlenmesi için SeismoStruct [23] yapı analiz programı kullanılmıştır.
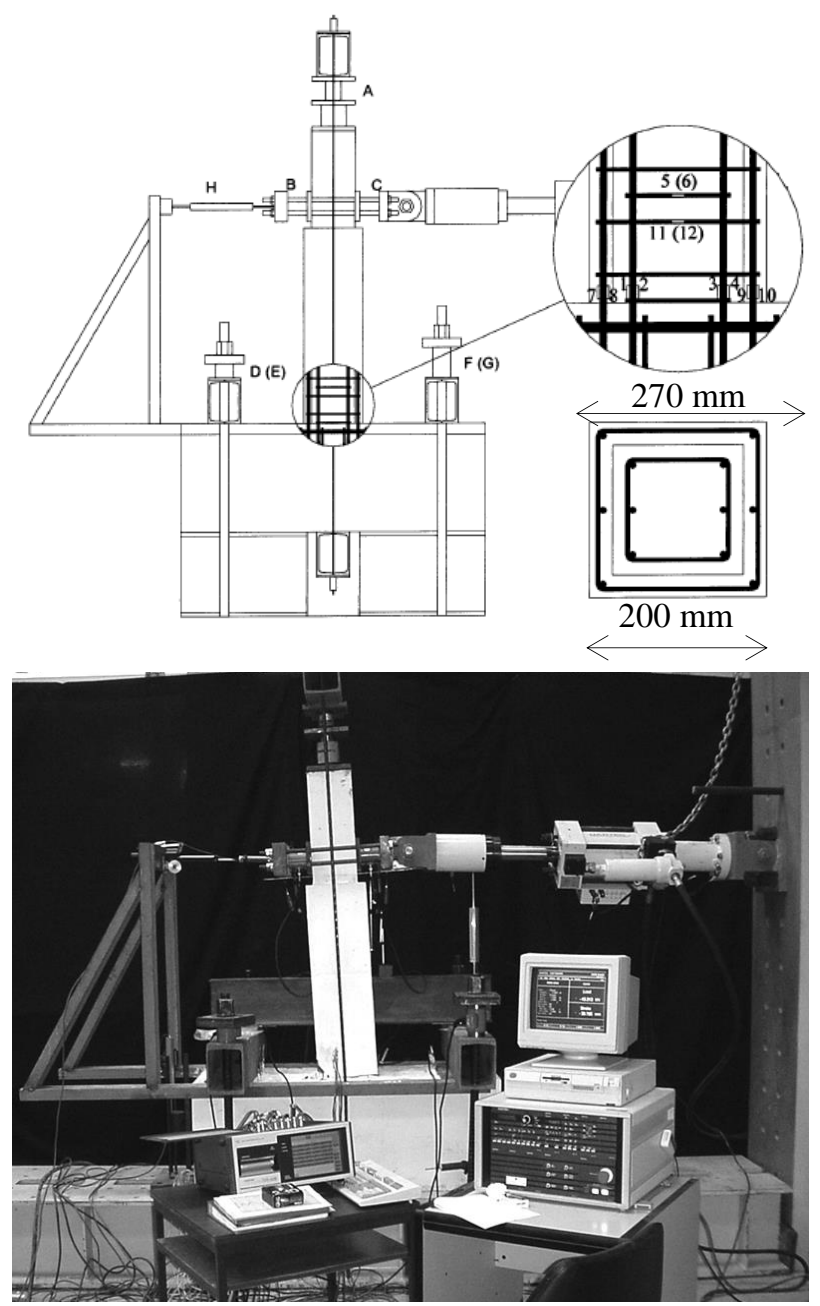

Şekil 2. Deney düzeneği [17]
SeismoStruct, betonarme yapıların statik ve dinamik yük etkisi altında geometri ve malzeme açısından doğrusal olmayan davranışının modellenmesinde kullanılan ve sonlu elemanlar esasına dayalı olarak çalışan yapısal analiz programıdır. Analitik sonuçların doğrulanmasında yararlanılan deneysel çalışmada kullanılan numunelerinin kesit ve malzeme özellikleri ile donatı dağılımları Tablo 1.'de özetlenmiştir.

Kolonların nümerik modellerinde çekirdek ve manto kesitinde kullanılan beton için Mander [24] beton modeli, enine ve boyuna donatılar için MenegottoPinto [25] çelik modeli kullanılmıştır. Beton modeli tek eksenli, doğrusal olmayan ve sabit sargı etkisi içeren bir model olup ilk olarak Madas [26] tarafindan belirtilen daha sonra Mander vd. [24] tarafından önerilen temel ilişkiyi ve Martinez-Rueda ve Elnashai [27] tarafindan önerilen çevrimsel kuralları esas alacak biçimde oluşturulmuştur. Söz konusu beton modeline Mander vd. [24] tarafından önerilen sargılama etkisi ile ilgili çevrimsel kurallar eklenmiştir. Çelik davranış modeli Filippou vd. [28] tarafından tanımlanan izotropik pekleşme kuralları ile Menegotto ve Pinto [25] tarafından önerilen gerilme-şekildeğiştirme ilişkisini birleştirmek suretiyle, Yassin [29] tarafindan oluşturulmuştur. Eduardo vd. [16-17] çalışmalarında çevrimsel yerdeğiştirme protokolü ECCS [30] esaslarına göre akma yerdeğiştirmesinin belirli katları esas alınarak belirlenmiştir. Nümerik çalışmada ise aynı çevrim sayılarının kullanıldığı Şekil 3'te görülen yerdeğiştirme protokolü uygulanmıştır. Esas alınan akma yerdeğiştirme değeri tek yönlü olarak uygulanan yükleme etkisi altında belirlenmiștir [17].

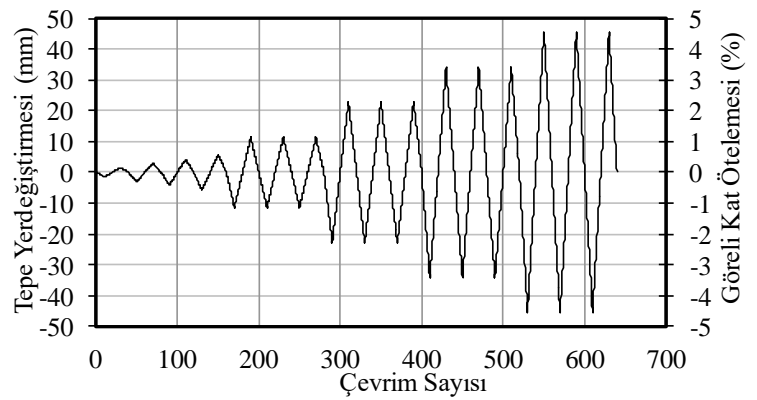

Şekil 3. Çevrimsel yerdeğiștirme protokolü

Kolon elemanların çevrimsel davranışının belirlenmesinde SeismoStruct [23] programının doğrusal olmayan statik çevrimsel ve itme analizi modülleri kullanılmıștır. Kesitlerin doğrusal olmayan davranışı program tarafından lif esasına dayalı olarak hesaplanan yayılı plastik şekildeğiştirme varsayımıyla otomatik olarak oluşturulduğu için ilave kesit analizine ihtiyaç duyulmamaktadır. Kolon elemanlar, geometri ve malzeme bakımından doğrusal olmayan özelliklere sahip elemanların modellenmesinde sıklıkla kullanılan yerdeğiştirme esaslı elastik olmayan çerçeve elemanlar olarak modellenmiştir. 
Tablo 1. Deney numunelerinin fiziksel özellikleri $[16,17]$

\begin{tabular}{|c|c|c|c|c|}
\hline $\begin{array}{c}\text { Çalışmalar } \\
\text { Yükleme tipi }\end{array}$ & \multicolumn{2}{|c|}{$\begin{array}{l}\text { Eduardo vd. [17] } \\
\text { Monotonik }\end{array}$} & \multicolumn{2}{|c|}{ Eduardo vd. [16] } \\
\hline Numune isimleri & Yalın Kolon (M1) & $\begin{array}{l}\text { Güçlendirilmiş } \\
\text { Kolon (M5) }\end{array}$ & Yalın Kolon (M1) & $\begin{array}{l}\text { Güçlendirilmiş } \\
\text { Kolon (M5) }\end{array}$ \\
\hline Çekirdek Beton Dayanımı (MPa) & 34.60 & 34.64 & 35.84 & 34.95 \\
\hline Manto Beton Dayanımı (MPa) & - & 79.79 & - & 78.25 \\
\hline $\begin{array}{l}\text { Boyuna ve Enine Donatıların } \\
\text { Akma Dayanımı (MPa) }\end{array}$ & 400 & 400 & 400 & 400 \\
\hline Kolon yüksekliği (mm) & 1350 & - & 1350 & - \\
\hline Kolon boyutları (mm) & $200 \times 200$ & - & $200 \times 200$ & - \\
\hline Çekirdek Kesitteki Boyuna Donatı & $6 \Phi 10$ & - & $6 \Phi 10$ & - \\
\hline Cekirdek Kesitteki Enine Donatı & $\Phi 6 / 150$ & - & $\Phi 6 / 150$ & - \\
\hline Manto Kesitindeki Boyuna Donatı & - & $6 Ф 10$ & - & $6 Ф 10$ \\
\hline Manto Kesitindeki Enine Donatı & - & $\Phi 6 / 75$ & - & $\Phi 6 / 75$ \\
\hline Manto Kalınlığı (mm) & - & 35 & - & 35 \\
\hline Manto Yüksekliği (mm) & - & 900 & - & 900 \\
\hline Eksenel Yük (kN) & 170 & 170 & 170 & 170 \\
\hline
\end{tabular}

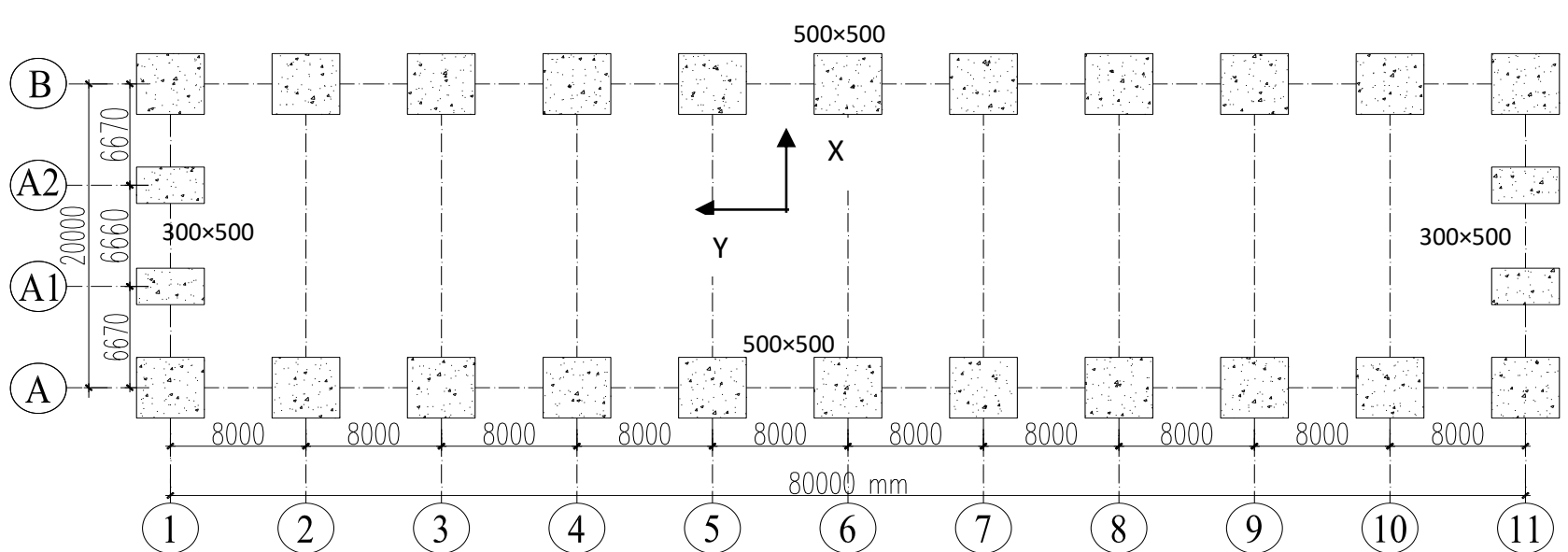

Şekil 4. Prefabrike yapı taşıyıcı sistem kolon yerleşimi

\section{Nümerik Çalışma}

Çalışmanın bu bölümünde moment aktarmayan kolon-kiriș birleșimine sahip olan ve TDY 2007 [31] esaslarına uygun olarak tasarlanan, tek katlı prefabrike betonarme bir yapı modeli esas alınmıştır. Gerçekleştirilen dinamik analizlerle betonarme kolonlarda manto uygulamasının yapının genel deprem davranıșına olan etkisi sayısal olarak irdelenmiștir. Nümerik modellerin olușturulmasında ve sayısal çözümlemelerde mantolama uygulamasının analitik modelinin de kurulmuş olduğu SeismoStruct yapı analizi programı kullanılmıştır. Yapı elemanlarında kullanılan beton sınıfı C30 ve donatı çeliği sınıfı ise S420'dir. Kabuk ve çekirdek beton davranışı için analitik modelde Mander beton modeli kullanılmıştır. Boyuna ve enine donatı davranışı ise Menegotto-Pinto çelik modeli ile temsil edilmiştir.

\subsection{Prefabrike yapının analitik modeli}

Sayısal çalışmalarda esas alınan yapı, prefabrike betonarme tek katlı çerçevelerden oluşan ve plandaki boyutları $20 \times 80 \mathrm{~m}$ olan endüstriyel bir yapı türüdür. Yapı sisteminde $x-x$ doğrultusunda $500 \times 500 \mathrm{~mm}$ boyutlarında kolonların bulunduğu 11 adet, $y-y$ doğrultusunda ise 2 adet ana (A, B) ve $300 \times 500 \mathrm{~mm}$ boyutlarında kolonların bulunduğu 2 adet tali $\left(\mathrm{A}_{1}, \mathrm{~A}_{2}\right)$ aks bulunmaktadır. Yapının plan görünümü Şekil 4'te verilmiștir. Tali akslar, yapının ön ve arka cephelerinde, cephe panellerinin bağlandığ kolonların yerleşimi için oluşturulan aksları ifade etmektedir.

Kenar ve iç aks çerçevelerinde kullanılan kare kesitli kolon $(500 \times 500 \mathrm{~mm})$ elemanlar, geometri ve donatı bakımından özdeștir. Eğimli çatı kiriși, kesit yüksekliği mesnetlerde $461 \mathrm{~mm}$ ve açıklık ortasında $1640 \mathrm{~mm}$ olacak şekilde imal edilmiştir. Kirişler, kolonların uç bölgesinde olușturulan kısa konsolların üzerine, kiriș ile kolon arasına $10 \mathrm{~mm}$ kalınlığında neopren ped konulmak suretiyle, yerleștirilmiştir. Kolonların toplam boyu $9.41 \mathrm{~m}$ ve kolonun soket temel içerisinde kalan boyu 1.20 m'dir. Dolayısıyla, kolon üst ucunun yerden yüksekliği $8.21 \mathrm{~m}$ olarak belirlenmiștir (Şekil 5). Kolon kesitinde, 4 adet $22 \mathrm{~mm}$ çapında boyuna donatı köşelerde, 4 adet $20 \mathrm{~mm}$ çapında boyuna donatı ise kenarlarda kullanılmıştır. Enine donatılar, $8 \mathrm{~mm}$ çapında olup kolon alt ve üst ucunda $100 \mathrm{~mm}$ aralık ile, orta bölgede ise $200 \mathrm{~mm}$ aralık ile yerleştirilmiştir. Kolon alt ucunda oluşturulan sıklaştırma bölgesi uzunluğu $3.60 \mathrm{~m}$ olup, soket temel dışında kalan uzunluğu 2.40 m'dir. Kolon üst uç sıklaștırma bölgesinin uzunluğu 900 mm'dir ve bu bölgenin 225 
mm uzunluğundaki kısmı guse içerisinde yer almaktadır. Kolon orta bölgesinin uzunluğu ise 4.40 m'dir. Eğimli çatı kirişlerinin üzerine eğilme momenti aktarmayacak şekilde mesnetlenen aşık kirişlerinin boyutları özdeştir. Benzer şekilde, kolonların üzerine eğilme momenti aktarmayacak şekilde mesnetlenen oluk kirişlerinin boyutları da özdeștir.

Güçlendirilmiş durumda üç boyutlu yapı modeli; betonarme manto uygulamasının soketlerin bulunduğu temel seviyesinden, belirlenen bir kolon yüksekliğine $\quad\left(\mathrm{h}_{\text {manto }}=2.4 \mathrm{~m}\right)$ kadar uygulandığ düşünülerek kurgulanmıştır. Yalın ve güçlendirilmiş durumda oluşturulan her iki analitik modelde de kolon elemanların temel bağlantı noktalarının tüm serbestliklerde tutulu olduğu varsayımı yapılmıştır.

Yapının kısa doğrultusunda yer alan idealize edilmiş çerçeve modeli ve yapıya ait genel bilgiler özet olarak Şekil 5.'te verilmiştir.

İncelenen prefabrike yapının üç boyutlu nümerik modeli Şekil 6.'da gösterilmektedir. Taşıyıcı sistemi meydana getiren tüm elemanlar, kesitleri ve sınır şartları ile nümerik model içerisine dâhil edilmiştir. Çatı kaplaması ağırlığı $12 \mathrm{~kg} / \mathrm{m}^{2}$, yapıya etkiyen kar yükü $75 \mathrm{~kg} / \mathrm{m}^{2}$ olarak dikkate alınmıştır. Kar yükü, hareketli yük katılım katsayısı $(n=0.30)$ kullanılarak yapı kütlesine dâhil edilmiștir. Eleman öz ağırlıkları nümerik model içerisinde, eleman birim hacim ağırlıkları aracılığıyla temsil edilmiştir. Yalın ve betonarme mantolu yapının 1. doğal titreşim periyodu sırasıyla 1.25 sn ve 1.10 sn olarak belirlenmiştir. Betonarme mantolama uygulaması, yapı titreşim periyodunu azaltmış yapının yatay rijitliğini arttırmıştır.

Eğik çatı kirişinin değişken kesitli biçimi, SeismoStruct programının sınırlarına bağlı kalınarak eğik çatı kirişi, oluk kirişi-eğik çatı kirişi ve aşık kirişi-eğik çatı kirişi birleșim noktaları arasında, 10 parçaya bölünerek temsil edilmiştir. Eğik çatı kirişinin her iki ucuna, kendi düzlemi içerisinde eğilme momenti mafsalı atanmıștır. Eğik çatı kiriși ekseni ile așık konumlarının birleştirilmesi için, rijitlikleri büyük olan tali çubuk elemanlar atanmıştır. Așık ve oluk kirişleri analitik modelde elastik çubuk elemanlar olarak tanımlanmıştır. Bu elemanların her iki ucuna, eğilme eksenleri etrafında eğilme momenti mafsalları atanmiştır.

\subsection{Analitik modelin deney sonuçlarıyla karşılaştırılması}

Mantolu ve yalın kolonların statik itme ve statik çevrimsel analizlerinden elde edilen yükyerdeğiştirme sonuçları literatürde var olan deneysel sonuçlarla karşılaştırılmıştır. Eduardo vd. [16] tarafından yapılan çalışmada monotonik yük etkisi altındaki mantolu M5 numunesine ait yükyerdeğiştirme ilişkisine grafik ortamda yer verilmediği için, tek doğrultuda gerçekleştirilen itme analizi sonuçları Şekil 7.'de çevrimsel deney sonuçları ile karşılaştırılabilmiştir.

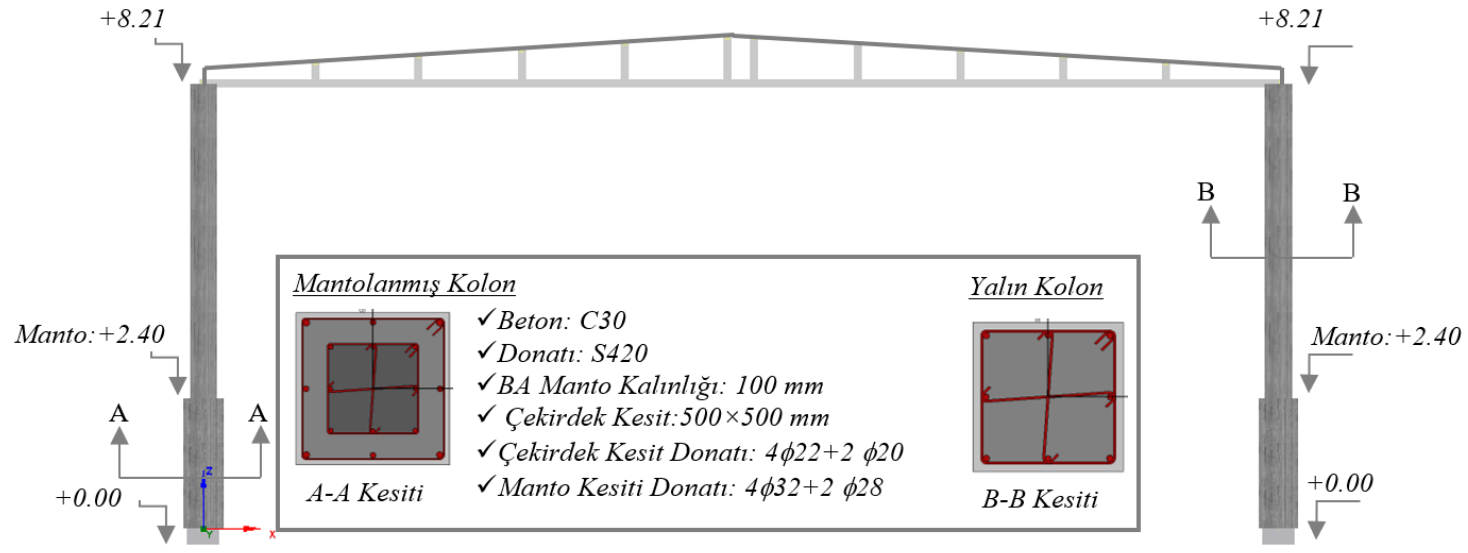

Şekil 5. Çerçeve sistem geometrik büyüklükler



Şekil 6. Betonarme mantolu ve yalın prefabrike yapının analitik modelleri 


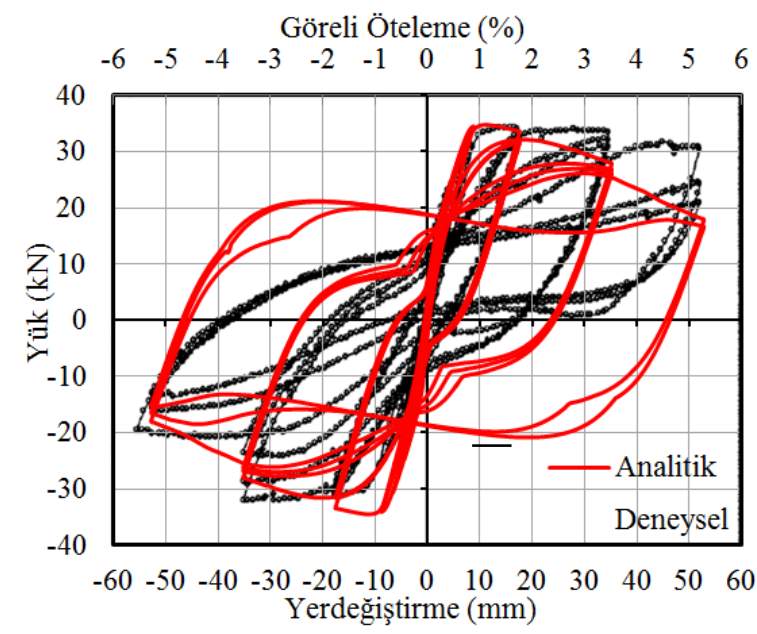

Yalın Kolon (M1) Çevrimsel Davranışı Göreli Öteleme (\%)

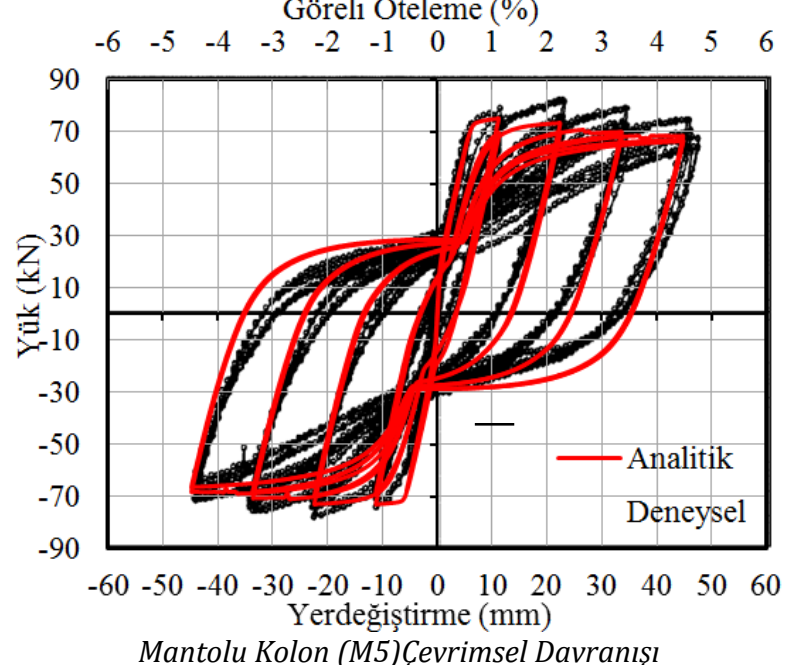

Göreli Öteleme (\%)

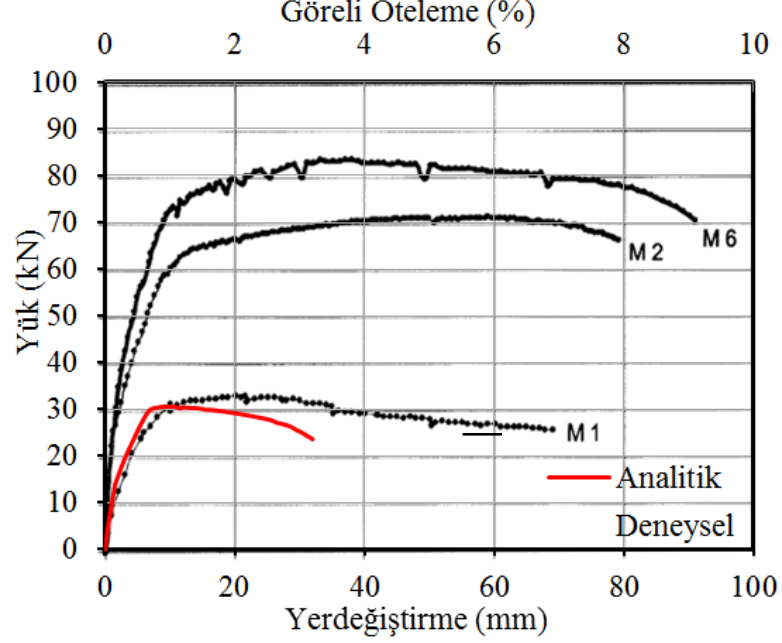

Yalın Kolon (M1) Monotonik Davranışı Göreli Öteleme (\%)

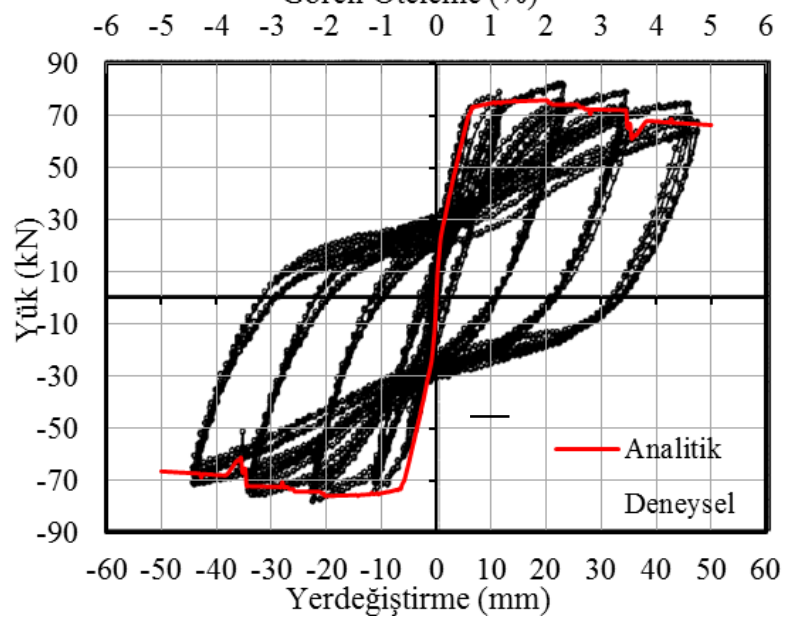

Mantolu Kolon (M5) Monotonik Davranışı

Şekil 7. M1 ve M5 numunelerinin deneysel sonuçları ile nümerik sonuçların karşılaştırılması

Yalın ve mantolu kolonlar için oluşturulan modellerin analizlerinden elde edilen sonuçlar, $\pm \% 3$ göreli öteleme sinırları içerisinde ulaşılan en büyük dayanım, bașlangıç rijitliği, ulaşılan yerdeğiștirme hedefleri ve en büyük dayanım sonrası davranıș gibi büyüklükler açısından deneysel sonuçlar ile iyi bir uyum göstermiştir.

\subsection{Deprem kayıtları seçimi}

Prefabrike yapılarda BA mantolama etkisinin belirlenebilmesi için gerçekleştirilen dinamik analizlerde, yapının her iki ortogonal doğrultusunda deprem kaydı aynı anda etkitilmiştir. TDY-07'de belirtilen ilkeler gereği, yapıya, yapının bulunduğu bölgeye ve zemine göre belirlenen elastik ivme spektrumu ile ilgili şartları sağlayan toplam 7 adet deprem ivme kaydı seçilmiștir. Kayıtlar PEER NGA [32] veri tabanından alınmıștır. Deprem kayıtlarına ait süreler ile kayıtların iki yatay bileşenine ait en büyük yer ivmesi büyüklükleri Tablo 2.'de sunulmuştur.

Dinamik analiz için seçilmiş olan 7 adet deprem kaydının her iki yatay bileşenine ait elastik ivme spektrumları ile ortalamaları, birinci derece deprem bölgesi ve Z2 sınıfı zemin için TDY-07'ye göre oluşturulan elastik ivme spektrumu ile birlikte Şekil 8.'de sunulmuştur.

Tablo 2. Seçilen deprem kayıtları

\begin{tabular}{|c|c|c|c|c|}
\hline Kayıt & Kayıt İsmi / & Maksimun & n İve (g) & Kayıt süresi \\
\hline \# & Ístasyon & X Doğrultusu & Y Doğrultusu & $(s n)$ \\
\hline 1 & $\begin{array}{l}\text { Superstition } \\
\text { Hills/Parachute } \\
\text { Test Site S5051 }\end{array}$ & 0.38 & 0.45 & 22.31 \\
\hline 2 & Erzincan / Erzikan & 0.50 & 0.52 & 20.78 \\
\hline 3 & $\begin{array}{c}\text { Imperial Valley / } \\
\text { El Centro Array } \\
\# 4\end{array}$ & 0.49 & 0.36 & 39.00 \\
\hline 4 & $\begin{array}{c}\text { Imperial Valley / } \\
\text { El Centro Array } \\
\# 6\end{array}$ & 0.44 & 0.41 & 39.04 \\
\hline 5 & $\begin{array}{c}\text { Northridge / CA } \\
\text { Sylmar, Jensen Flt } \\
\text { Plt }\end{array}$ & 0.57 & 1.02 & 28.62 \\
\hline 6 & $\begin{array}{l}\text { Northridge / } \\
\text { Newhall-Fire } \\
\text { Station }\end{array}$ & 0.58 & 0.59 & 40.00 \\
\hline 7 & $\begin{array}{c}\text { Northridge / } \\
\text { Rinaldi Receiving } \\
\text { Sta }\end{array}$ & 0.49 & 0.83 & 19.91 \\
\hline
\end{tabular}



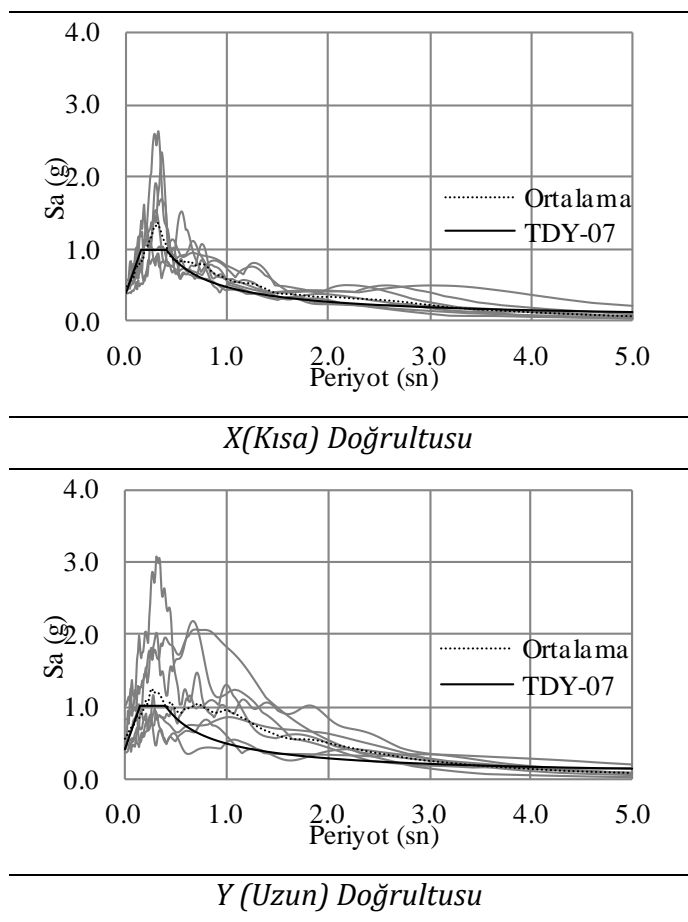

\section{Analiz Sonuçları}

Betonarme mantolama yönteminin prefabrike yapıların deprem performansına etkisinin belirlenebilmesi için, analiz sonuçları bir takım yapısal parametreler kapsamında değerlendirilmiștir. $\mathrm{Bu}$ parametreler; göreli öteleme, toplam taban kesme kuvveti ve kolon kesitlerinde oluşan şekil değiștirme düzeyleri olarak seçilmiştir.

\subsection{Göreli ötelemeler}

Prefabrike yapının deprem performansı, yapının kısa (X-X) doğrultusuna paralel olan 11 çerçeve içerisinden 3 tanesi seçilerek değerlendirilmiştir. Ele alınan çerçeveler soldan sağa doğru sıralı olarak isimlendirilmek suretiyle Şekil 9'da gösterilmektedir. Seçilen 1. 3. ve 6. çerçeveleri için, doğrusal olmayan dinamik analizlerden elde edilen, yatay tepe yer değiştirme geçmişleri sırasıyla Şekil 10, 11 ve 12 'de verilmiștir.

Şekil 8. Elastik ivme spektrumları

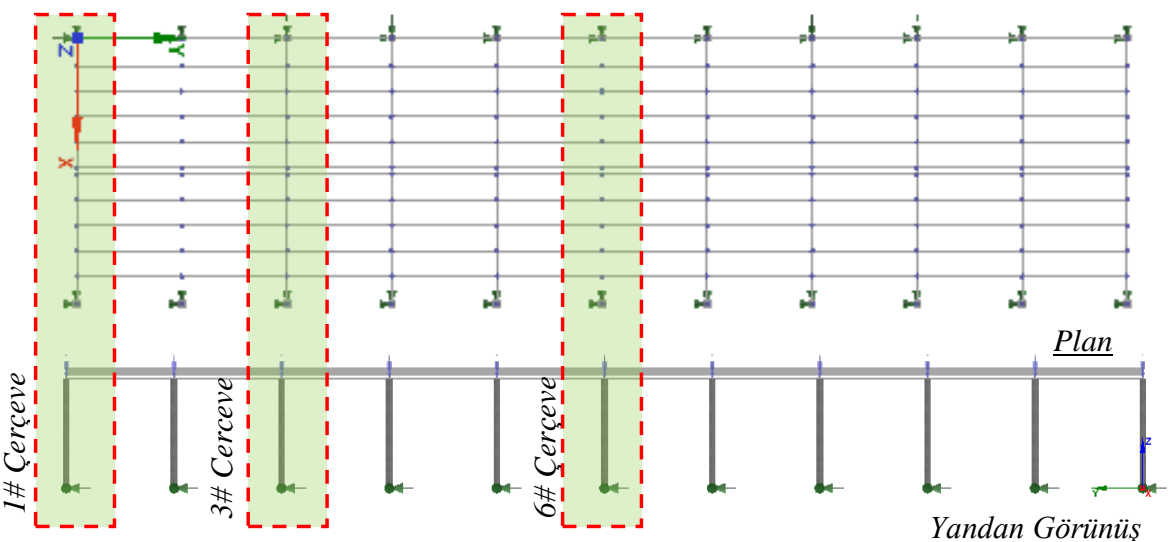

Şekil 9. Ele alınan çerçeveler ve yapı içerisindeki konumları
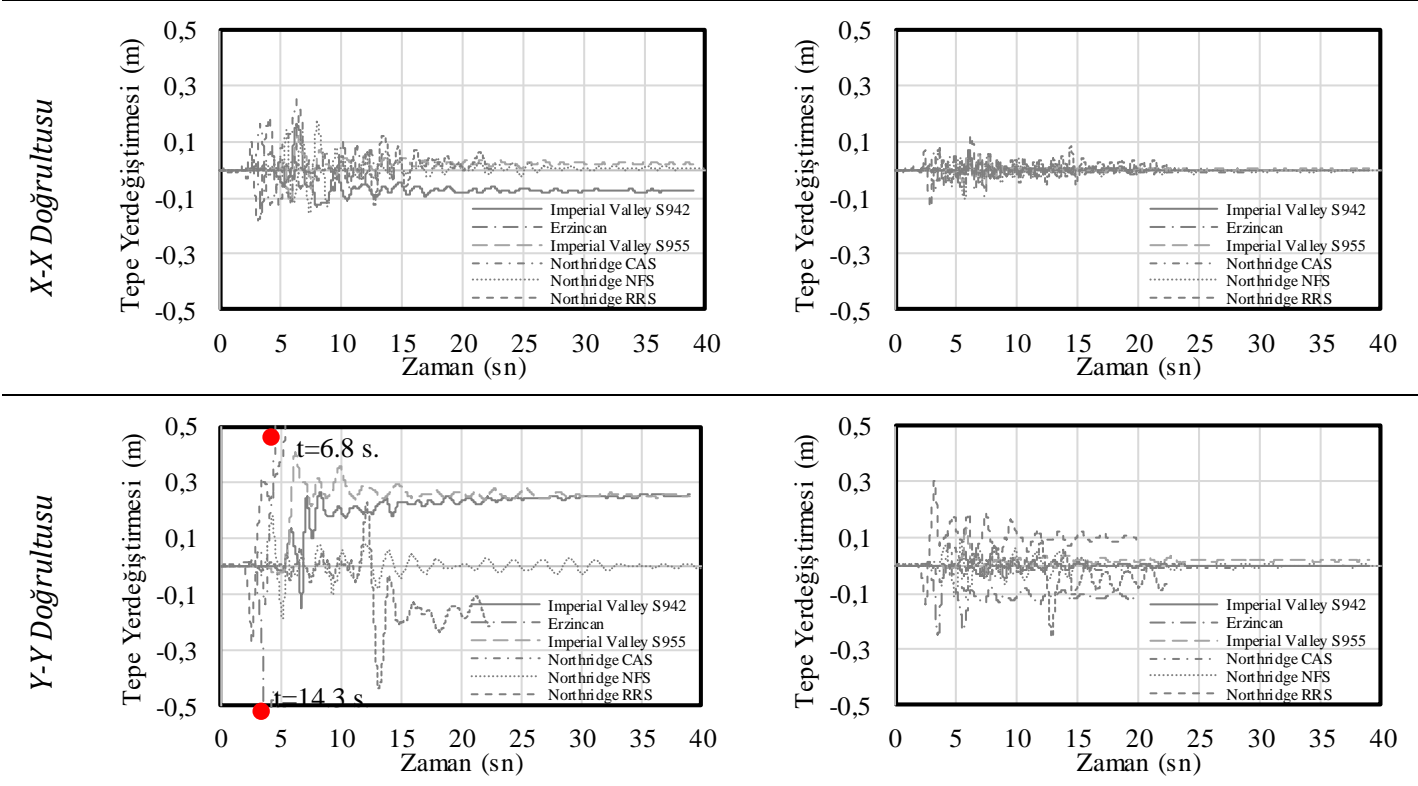

Yalın Cerçeve

Güçlendirilmiş Çerçeve

Şekil 10. 1. çerçeve tepe yatay yer değiştirme geçmişleri 

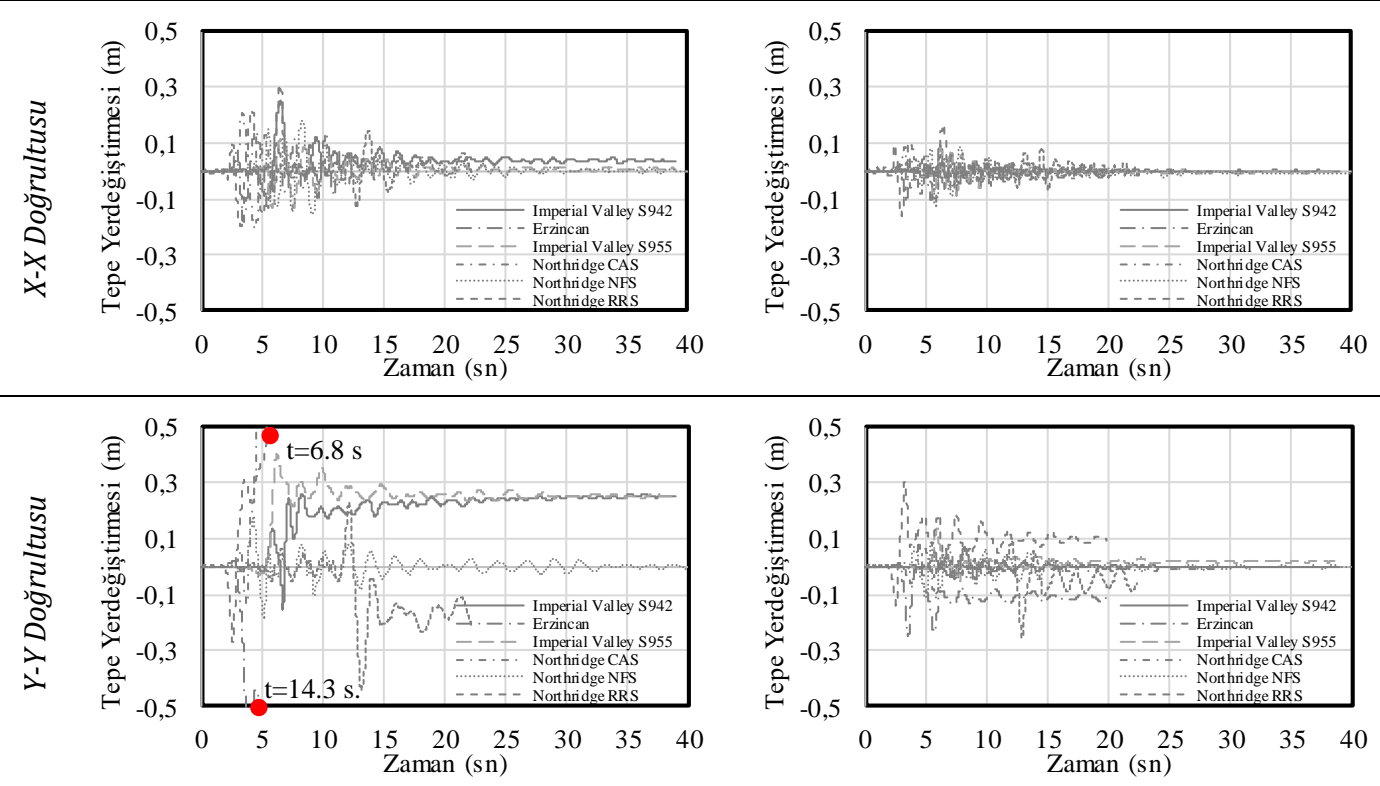

Yalın Cerçeve

Güçlendirilmiş Cerçeve

Şekil 11. 3. çerçeve tepe yatay yer değiştirme geçmişleri
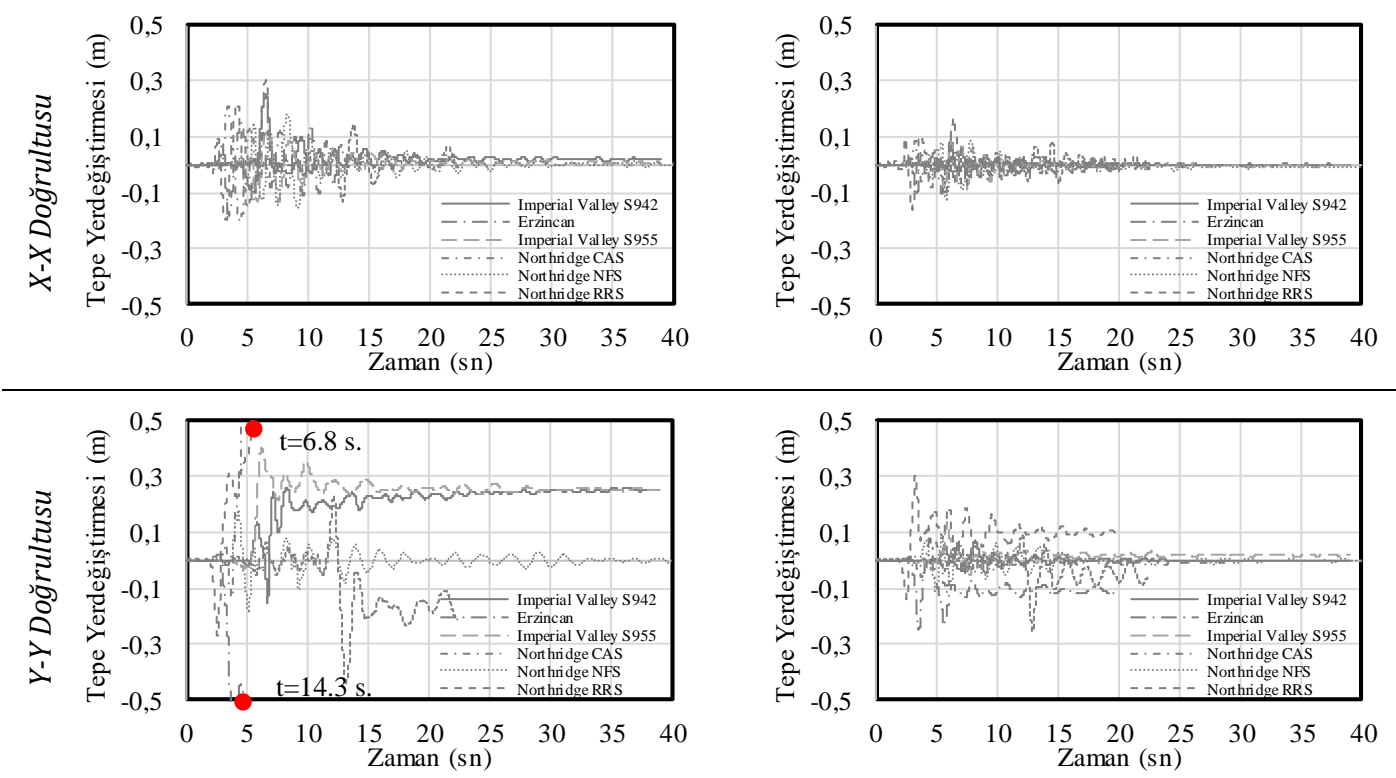

Yalın Çerçeve

Güçlendirilmiș Cerçeve

Şekil 12. 6. çerçeve tepe yatay yer değiştirme geçmişleri

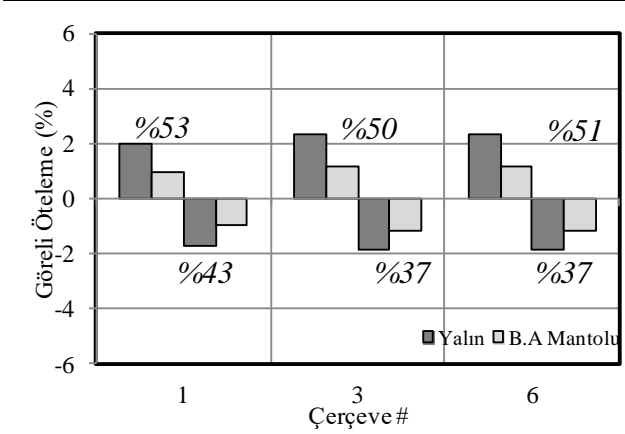

$X-X$ Doğrultusu

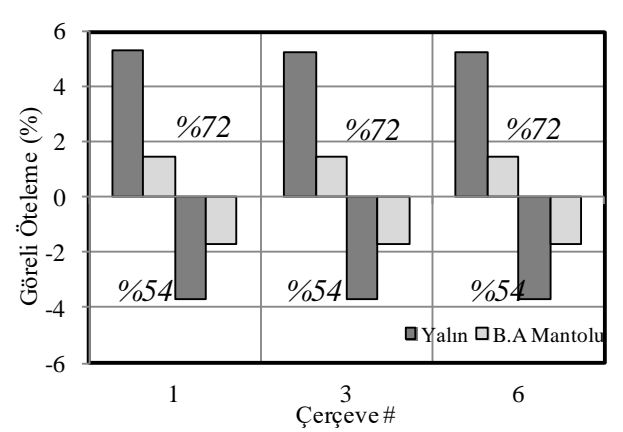

$Y$-Y Doğrultusu

Şekil 13. Yapının her iki doğrultudaki en büyük ve en küçük göreli ötelemelerin azalma oranları

Sayısal çalışmalar BA manto uygulamasının prefabrike yapıda esas alınan çerçevelerin yatay tepe yer değiştirme istemlerini önemli ölçüde azalttığını göstermektedir. Prefabrike yapıya ait söz konusu 
çerçevelerin yatay tepe yer değiştirmelerinin en büyük ve en küçük değerlerinin göreli kat ötelemesi cinsinden ortalamaları Şekil 13'te verilmiştir.

Kısa doğrultuda her üç çerçeve sisteme ait göreli ötelemelerin betonarme mantolu durumda \%37 ile \%53 arasında değișen oranlarda azaldığ görülmektedir. Analiz sonuçları BA manto etkisinin, uzun doğrultuda en büyük ve en küçük göreli öteleme ortalamalarını \%54 ile \%72 arasında değişen oranlarda azalttığını göstermektedir. Analiz sonuçları; bazı deprem kayıtlarının özellikle güçlendirilmemiș yapının uzun doğrultusunda oluşturdukları yüksek yer değiştirme istemleri nedeniyle dayanım aşımına sebep olduklarını göstermiştir. Analizin sonlanmak durumunda kaldığı kayıtlar ve dayanım kaybının görüldügü deprem süresi $(t)$ ilgili grafiklerde belirtilmiştir.

\subsection{Taban kesme kuvveti}

Taban kesme kuvveti kapsamında değerlendirilen sonuçlar her kayıt için elde edilen en büyük ve en küçük taban kesme kuvvetleri Şekil 14.'te verilmektedir. Analizler sonucunda yapının kısa doğrultusunda güçlendirilmiş durum için Northridge/CA Sylmar kaydı etkisi altında taban kesme kuvveti $2150 \mathrm{kN}$ olarak elde edilmiştir. Uzun doğrultuda ise yalın durum için Erzincan kaydı etkisi altında $2450 \mathrm{kN}$ seviyesinde bir taban kesme kuvveti elde edilmiștir.
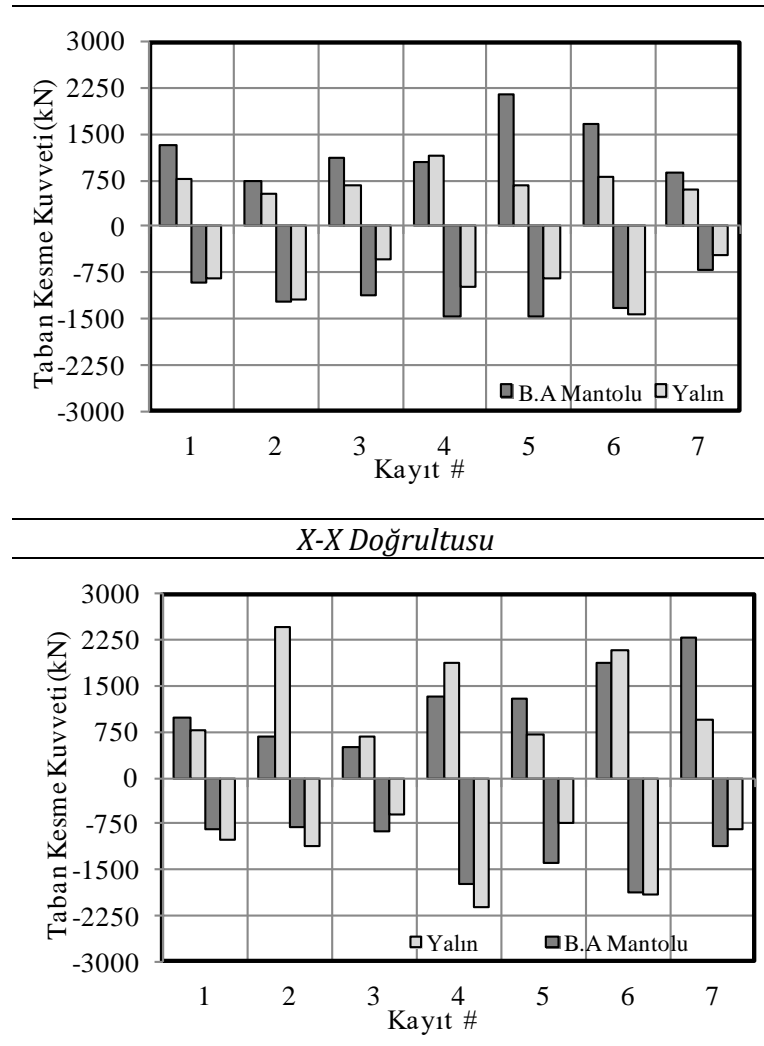

$Y$-Y Doğrultusu

Şekil 14. En büyük ve en küçük taban kesme kuvvetleri değişimi
Analiz sonuçları, taban kesme kuvvetlerinin en büyük ve en küçük değerlerinin yapının kısa doğrultusunda ( $X$-X doğrultusu) mantolu durumda artma eğiliminde olduğunu, uzun doğrultusunda ( $Y$ - $Y$ doğrultusunda) ise benzer eğilimin olmadığını göstermiştir. Taban kesme kuvvetlerinin en büyük ve en küçük değerlerinin ortalamaları her iki dik doğrultu için Şekil 15'te verilmiştir. Taban kesme kuvvetlerinin ekstramum değerlerinin ortalamaları kısa doğrultuda ( $X$-X doğrultusu) \%30-\%70 arasında değişim oranlarda artmıştır. Uzun doğrultuda ( $Y$ - $Y$ doğrultusu) ise bu artış oranı \%3-\%5 arasında kalmıştır.

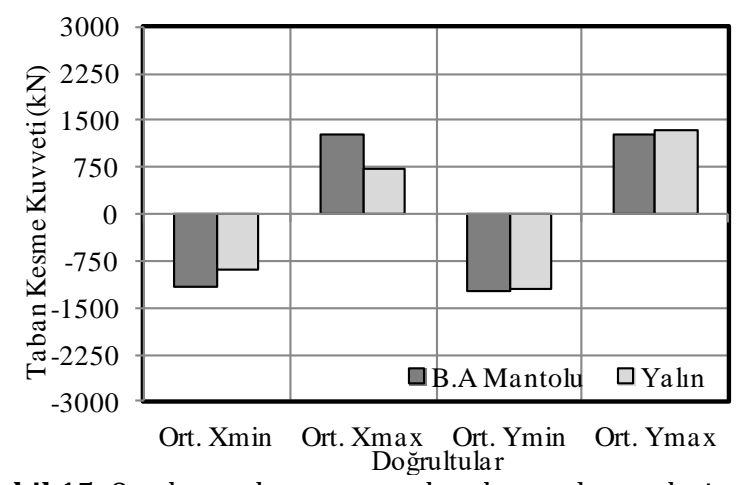

Şekil 15. Ortalama ekstramum taban kesme kuvvetleri

Önerilen güçlendirme yöntemi yapı elemanlarında oluşan kesme kuvveti değerlerini değiştirmiştir. Bu noktada artan kuvvetlerinin oluşturabileceği muhtemel kesme zafiyetleri kontrol etmek amaciyla bazı çerçevelerin (\#1, \#3 ve \#6) kolonlarında oluşan ortalama kesme kuvvetleri esas alınarak kesme tahkiki Tablo 3.'te yapılmıştır.

Boyutları $50 \times 50 \mathrm{~cm}$ ve donatı çeliği sınıfı S420 olan kolon elemanın, beton katkısının ihmal edildiği ve etriyenin en seyrek olduğu orta bölgede $(\phi 8 / 20 \mathrm{~cm})$ durumda $V_{r}$, denklem (1) kullanılarak hesaplanmıștır [33].

$$
V_{r}=A_{s w} \times f_{d y w d} \times d / s
$$

Denklemde yer alan ifadeler, etriye toplam kesit alanı $\left(A_{s w}\right) 150 \mathrm{~mm}^{2}$, etriye çeliğinin hesap akma dayanımı ( $\left.f_{y w d}\right) 365 \mathrm{MPa}$, kolon kesiti eğilme yönündeki faydalı yüksekliği (d) $475 \mathrm{~mm}$, etriye adım aralığı (s) $200 \mathrm{~mm}$ olmak üzere kolon orta bölgesindeki kayma dayanımı $\mathrm{V}_{\mathrm{r}}=300 \mathrm{kN}$ olarak hesaplanmıștır. Kolon boyunca kesme kuvvetinde bir değişim olmadığı değerlendirildiğinde, manto uygulamasının olmadığ kolon orta bölgesinde sağlanan kesme güvenliği mantolu kesitlerde fazlasıyla sağlanmış olacaktır.

Kolon-kiriş birleşim bölgesinde kayma dayanımı hesabı için Psycharis ve Mouzakis [34] tarafindan moment aktarmayan birleşimler için önerilen ampirik bağıntı kullanılmıştır, (2). Prefabrike yapının kolon-kiriş birleşim bölgesinde $26 \mathrm{~mm}$ çapında iki adet rod kullanılmıştır. Denklem (2)'de " $d$ " rodun kiriş yüzüne olan boyuna doğrultudaki mesafesi, " $D$ " ise rod 
çapını ifade etmek üzere " $d / D$ ” oranı 6.73 olarak hesaplanmıștır. Düğüm noktasında moment aktarılma özelliğine dayalı olarak $C_{0}$ katsayısı 0.90 ile 1.10 arasında değişmekte olup burada söz konusu durum için $C_{0}$ için "1.00" değeri esas alınmıştır. Deneysel yöntemdeki belirsizlikler ile kullanılan deneysel verinin sınırlı sayıda olması dolayısıyla $\gamma_{R}$ için "1.30" değerinin kullanılması önerilmiştir. Kolon-kiriş birleşim kesme dayanımı, önerilen bağıntı kullanılarak, malzeme karakteristik dayanımları ile hesaplanacak olursa $116 \mathrm{kN}$ değeri elde edilmektedir. $\mathrm{Bu}$ durumda prefabrike yapının diğer kritik bölgesi olan kolon-kiriş bölgesinde de kesme güvenliğinin sağlandığı görülmektedir.

$$
R_{d}=\frac{c_{0}}{\gamma_{R}} n D^{2} \sqrt{f_{c d} f_{y d}} \quad \frac{d}{D}>6.00
$$

\section{3. Şekil değiştirme seviyeleri}

Doğrusal olmayan dinamik analiz sonuçlarına göre, yalın ve mantolu yapı sistemlerinin 1 . ve 6 . çerçevelerinde yer alan kolonların alt uç kesitlerinde, tarafsız eksene en uzak beton liflerinden alınan şekil değiştirme büyüklüklerinin geçmişi karşılaştırmalı olarak Şekil 17.'de verilmiştir. Mantolanmanın uygulanmadığı yalın durumda özellikle Northridge/CA Sylmar, Northridge/Rinaldi ve Imperial Valley deprem kayıtlarının etkitildiği analizlerde dayanım kaybından dolayı Şekil 17'de yüksek şekil değiştirme seviyeleri görülmektedir. $\mathrm{Bu}$ durumda oluşan sayısal kararsızlıklar analizin sonlandırılmasına sebep olmuştur. Karşılaştırma için esas alınan beton lifleri kolon kesitleri üzerinde yeşil renk ile Şekil 16.'da gösterilmiştir.

Tablo 3. Kritik çerçevelerin kolonlarında oluşan kesme kuvvetleri

\begin{tabular}{|c|c|c|c|c|c|}
\hline \multirow[b]{2}{*}{$\begin{array}{c}\text { Cerçeve } \\
\#\end{array}$} & \multirow[b]{2}{*}{ Doğrultu } & \multicolumn{2}{|c|}{ İç Kuvvet (kN) } & \multirow{2}{*}{$\begin{array}{c}\text { Dayanım } \\
(k N) \\
\text { Kolon Orta } \\
\text { Bölgesi }\end{array}$} & \multirow[b]{2}{*}{ Kontrol } \\
\hline & & $\begin{array}{c}\text { Yalın } \\
\text { Cerçeve }\end{array}$ & $\begin{array}{c}\text { BA } \\
\text { Mantolu } \\
\text { Cerçeve }\end{array}$ & & \\
\hline \multirow{2}{*}{1} & $X-X$ & 33.00 & 50.95 & \multirow{6}{*}{300} & $\checkmark$ \\
\hline & $Y-Y$ & 64.09 & 64.79 & & $\checkmark$ \\
\hline \multirow{2}{*}{3} & $X-X$ & 41.92 & 55.22 & & $\checkmark$ \\
\hline & $Y-Y$ & 62.08 & 60.11 & & $\checkmark$ \\
\hline \multirow{2}{*}{6} & $X-X$ & 42.27 & 55.21 & & $\checkmark$ \\
\hline & $Y-Y$ & 64.39 & 59.40 & & $\checkmark$ \\
\hline
\end{tabular}
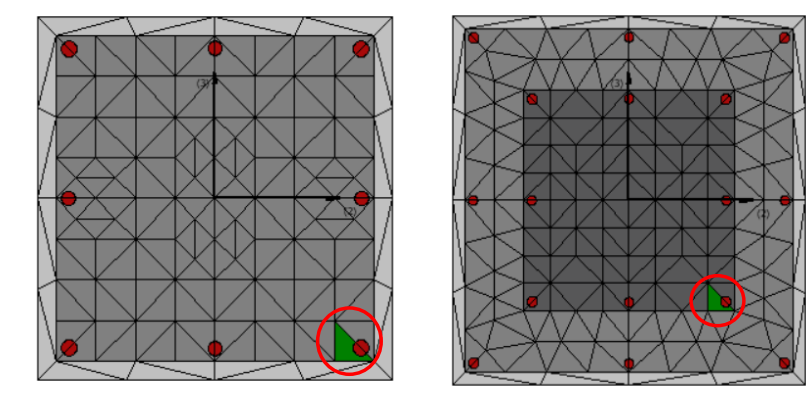

Yalın Kolon Çekirdek Kesiti

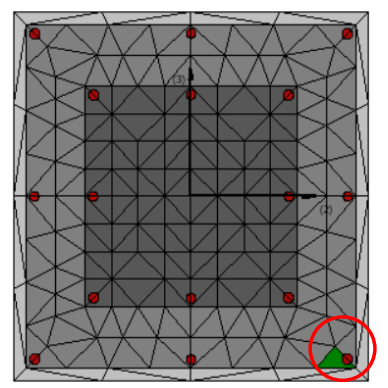

Kolon Manto Bölgesi

Şekil 16. Karşılaştırmaya esas alınan beton lifleri
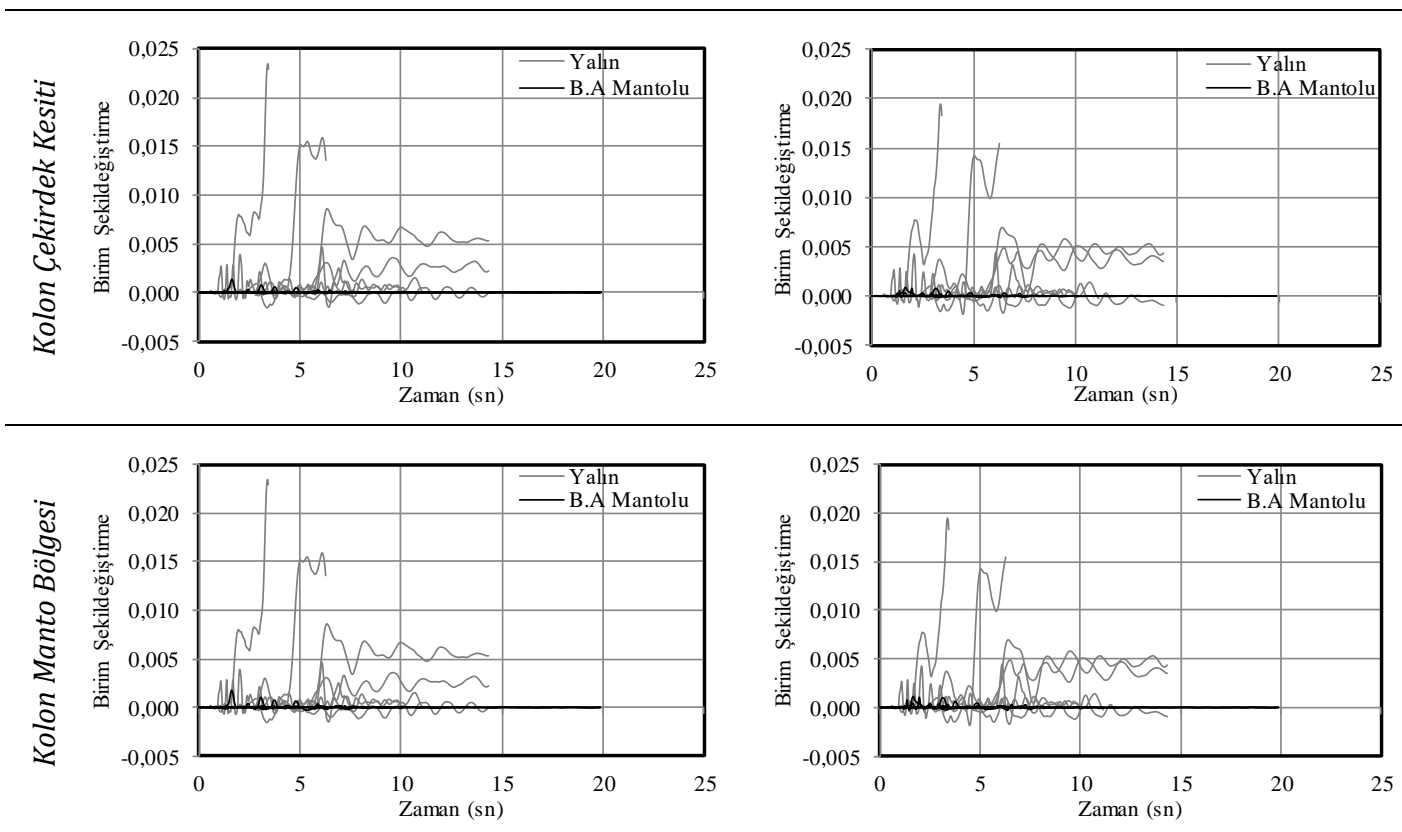

Şekil 17. Şekildeğiştirme geçmişleri

1. Cerçeve

6.Cerçeve 
Dinamik analiz sonuçları, seçilen çerçevelerde yer alan kolonlarının alt uç kesitlerinde oluşan şekildeğiştirme seviyelerinin BA mantolama uygulaması sayesinde önemli ölçüde azaldığını göstermektedir. Seçilen kolonlarda oluşan ortalama şekildeğiştirme seviyeleri 0,0080 değerinden, mantolanmış durumda hem çekirdek bölgesinde hem manto bölgesinde 0,0005 değerlerine gerilemiştir. Betonarme elemanları kesit birim şekildeğiştirme kapasiteleri ile ilgili TDY-07'de [31] verilen performans sınırlar değerleri esas alındığında, yalın durumdayken kesit güvenlik sınırı (GV) civarında olan yapının mantolama uygulaması sayesinde kesit performansının minimum hasar sınırının (MN) altına çekilmesini sağlamıştır, Tablo 4.

Tablo 4: Kesit hasar şekil değiştirme üst sınırları [31]

\begin{tabular}{|l|c|c|}
\hline Kesit Hasar Sınırları & Beton & Celik \\
\hline Minimum Hasar Sınırı (MN) & 0,0035 & 0,01 \\
\hline Güvenlik Sınırı (GV) & 0,0135 & 0,04 \\
\hline Göçme Sınırı (GÇ) & 0,018 & 0,06 \\
\hline
\end{tabular}

\section{Sonuçlar}

Betonarme mantolama özellikle prefabrike yapıların güçlendirilmesi için oldukça kolay uygulanabilen bir güçlendirme yöntemidir. $\mathrm{Bu}$ yöntemin mevcut bir prefabrike yapının deprem performansına etkisi, gerçekleştirilen doğrusal olmayan dinamik analiz sonuçlarından yararlanılarak belirlenmiştir. Çalışma kapsamında ulaşılan sonuçlar aşağıda sıralanmıştır;

1. Betonarme mantolama uygulaması için nümerik bir model geliştirilmiştir. Geliştirilen modelin sonuçları, literatürde var olan deneysel çalışmanın sonuçları ile karşılaştırılmıştır. Yalın ve mantolu kolonların nümerik modelleri, itme ve çekme doğrultularında belirli sınırlar içerisinde ulaşılan en büyük dayanım, başlangıç rijitliği ve yük-yerdeğiştirme ilişkilerinin geri dönüş kollarının eğimi gibi önemli büyüklükleri başarı ile temsil edebilmiş ve analiz sonuçları deneysel sonuçlar ile oldukça iyi bir uyum içerisinde olmuştur.

2. Prefabrike yapının \#3 numaralı çerçevesi esas alındığında betonarme mantolama uygulaması sayesinde; tepe yerdeğiştirmesi değerlerinin yapının kısa doğrultusunda 0.3 m'den 0.15 m'ye; uzun doğrultuda ise yaklaşık $1 \mathrm{~m}^{\prime}$ den $0.3 \mathrm{~m}$ 'ye kadar azaldığı görülmüştür. Diğer çerçeveler kapsamında yapılan genel değerlendirmeye göre betonarme mantolama uygulamasıyla, ortalama en büyük ve en küçük göreli öteleme büyüklükleri yapının kısa doğrultusunda $\% 37-\% 53$ oranlarında, uzun doğrultusunda ise \%54-\%72 oranlarında azaldığı sonucuna varılmıştır.

3. Önerilen güçlendirme yöntemi, yapının deprem performansını ve rijitliğini artırmaktadır. Bu sebeple; artan iç kuvvetler, güçlendirmiş durum için yapısal eleman kapasitesi ile karşılaştırılarak güvenlik kontrolünün tekil eleman düzeyinde sağlanması gerekmektedir. Bu kapsamda yapılan kontrollerde yapı kolonlarında ve kolon-kiriş birleşim bölgesinde kesme güvenliği açısından herhangi bir zafiyet görülmemiştir.

4. Mantolama etkisiyle gerek kolon çekirdeğinde yer alan liflerde gerekse mantolanmış kesitte yer alan liflerde meydana gelen şekildeğiștirme büyüklükleri önemli ölçüde azalmıştır. Yalın durumdayken şekildeğiştirme büyüklükleri kesit için güvenlik sınırı (GV) civarındayken mantolama uygulaması ile şekildeğiştirme büyüklükleri kesit için minimum hasar sınırının (MN) altına çekilmiştir.

\section{Kaynaklar}

[1] Arslan, M.H., Korkmaz, H.H., Gulay, F.G. 2006. Damage and Failure Pattern of Prefabricated Structures after Major Earthquakes in Turkey and Shortfalls of the Turkish Earthquake Code. Engineering Failure Analysis, 13, 537-557.

[2] Saatcioglu, M., Mitchell, D., Tinawi, R., Gardner, N.J., Gillies, A.G., Ghoborah, A., Anderson, D.L., Lau, D. 2001. The August 17, 1999, Kocaeli (Turkey) Earthquake - Damage to Structures. Canadian Journal of Civil Engineering, 28: 715737.

[3] Wang R., Jirsa J.O., Wood S.L. 2009. Rehabilitation of Precast Industrial Buildings using Cables to Develop Diaphragm Action. In: Ilki A., Karadogan F., Pala S., Yuksel E. (eds) Seismic Risk Assessment and Retrofitting. Geotechnical, Geological and Earthquake Engineering, vol 10. Springer, Dordrecht.

[4] Marini, A., Meda, A. 2009. Retrofitting of R/C Shear Walls by Means of High Performance Jackets. Engineering Structures, 31(2009), 3059-3064.

[5] Minafò, G. 2015. A Practical Approach for the Strength Evaluation of RC Columns Reinforced with RC Jackets. Engineering Structures, 85(2015), 162-169.

[6] Minafo, G., Trapani, F. D., Amato, G. 2016. Strength and Ductility of RC Jacketed Columns: a Simplified Analytical Method. Engineering Structures, 122(2016), 184-195.

[7] Alejandra, B., Navarrete 0., Guerreroa, J. M. J., Díaza, M. J. 2016. Influence of RC Jacketing on the Seismic Vulnerability of RC Bridges. Engineering Structures, 123 (2016), 236-246.

[8] Dubey, R., Kumar P. 2016. Experimental Study of the Effectiveness of Retrofitting RC Cylindrical Columns Using Self-compacting Concrete Jackets. Construction and Building Materials, 124(2016), 104-117.

[9] Kalogeropoulos, G. I., Tsonos, A. G. 2014. Effectiveness of $\mathrm{R} / \mathrm{C}$ Jacketing of Substandard R/C Columns with Short Lap Splices. Structural Monitoring and Maintenance, 1(2014), 273-292. 
[10] Yuce, S. Z., Yuksel, E., Bingol, Y., Taskın, K., Karadogan, H. F. 2007. Local Thin Jacketing for the Retrofitting of Reinforced Concrete Columns. Structural Engineering and Mechanics, 27(2007), 589-607.

[11] Thermou, G. E., Pantazopoulou S. J., Elnashai, A. S. 2007. Flexural Behavior of Brittle RC Members Rehabilitated with Concrete Jacketing. Journal of Structural Engineering, 133(2007),1373-1384

[12] Thermou, G.E., Papanikolaou, V. K., Kappos A .J. 2014. Flexural Behaviour of Reinforced Concrete Jacketed Columns Under Reversed Cyclic Loading. Engineering Structures, 76(2014), 270-282.

[13] TDY 1998. Afet Bölgelerinde Yapılacak Yapılar Hakkında Yönetmelik, Bayındırlı ve İskan Bakanlığı, Ankara, Türkiye.

[14] UBC-97. 1997. Uniform Building Code. In: International Conference of Buildings Official, USA.

[15] Eurocode-8-98. 1998. Design Provisions for Earthquake Resistance of Structures. European Union, European Prestandarts, Brussel.

[16] Júlio Eduardo. N. B. S., Branco, F. A. B. 2008. Reinforced Concrete Jacketing-Interface Influence on Cyclic Loading Response. ACI Structural Journal, 105(2008), 1-7.

[17] Júlio, Eduardo. N. B. S., Branco, F. A. B., Silva, V. D. 2005. Reinforced Concrete Jacketing-Interface Influence on Monotonic Loading Response. ACI Structural Journal, 102(2005), 252-257.

[18] Ilki, A., Darilmaz, K., Bakan, I., Zorbozan, M., Yuksel, E., Saruhan, H. 1998. Jacketing of Prefabricated Columns. 2nd Japan-Turkey Workshop on Earthquake Engineering, Istanbul, Turkey, 329-336.

[19] Ersoy, U., Tankut, T., Suleiman, R. 1993. Behavior of Jacketed Columns, ACI Structural Journal, 90(1993), 288-293.

[20] Rodriguez, M., Park, R. 1994. Seismic Load Tests on Reinforced Concrete Columns Strengthened by Jacketing. ACI Structural Journal, 91(1994), 150-159.

[21] Vandoros, K.G., Dritsos, S. E. 2006. Axial Preloading Effects when Reinforced Concrete Columns are Strengthened by Concrete Jackets. Progress in Structural Engineering and Materials, 8(2006), 79-92.

[22] Ozturk, B. Demiralan, F. Civalek O. " Seismic Drift Response of Precast Concrete Building Structures Located in Earthquake-Prone Regions in Turkey Considering Nonlinear Analysis Procedures" The $14^{\text {th }}$ World Conference on Earthquake Engineering, October 12-17, 2008, Beijing, China
[23] SeismoStruct. A Computer Program for Static and Dynamic Nonlinear Analysis of Framed Structures. URL: http://www.seismosoft.com.

[24] Mander, J.B., Priestley, M.J.N., Park R. 1988. Theoretical Stress-Strain Model for Confined Concrete. Journal of Structural Engineering, 114(1988), 1804-1826.

[25] Menegotto, M., Pinto, P.E. 1973. Method of Analysis for Cyclically Loaded RC Plane Frames Including Changes in Geometry and Non-Elastic Behaviour of Elements Under Combined Normal Force and Bending. Symposium on the Resistance and Ultimate Deformability of Structures Acted on by Well Defined Repeated Loads, International Association for Bridge and Structural Engineering, Zurich, Switzerland, 15-22.

[26] Madas, P. 1993. Advanced modeling of composite frames subjected to earthquake loading, Imperial College, University of London, PhD Thesis, London, UK.

[27] Martinez-Rueda J. E., Elnashai, A. S. 1997. Confined Concrete Model Under Cyclic Load, Materials and Structures, 30(1997), 139-147.

[28] Filippou, F.C., Popov, E.P., Bertero, V.V. 1983. Effects of Bond Deterioration on Hysteretic Behaviour of Reinforced Concrete Joints. Report EERC 83-19, Earthquake Engineering Research Center, University of California, Berkeley.

[29] Yassin, M. H. M. 1994. Nonlinear analysis of prestressed concrete structures under monotonic and cyclic loads. University of California, PhD Thesis, Berkeley, USA.

[30] ECCS. 1986. Recommended Testing Procedures for Assessing the Behaviour of Structural Steel Elements under Cyclic Loads. European Convention for Constructional Steelwork, 1986, Publication No. 45.

[31] TDY 2007. Deprem Bölgelerinde Yapılacak Binalar Hakkında Yönetmelik, Bayındırlık ve İskan Bakanlığı, Ankara, Türkiye.

[32] NGA, P.N., 2019. Pacific Earthquake Engineering Research Center: NGA Database. University of California, Berkeley, CA. (http://peer.berkeley.edu/peer-strong-groundmotion-databases/)

[33] TS 500. 2000. Betonarme Yapıların Tasarım ve Yapım Kuralları, Türk Standartları Enstitüsü, Ankara.

[34] Psycharis, I. N., Mouzakis, H.P. 2012. Shear Resistance of Pinned Connections of Precast Members to Monotonic and Cyclic Loading. Engineering Structures, 41(2012), 413-427. 